\title{
PERBANDINGAN REGRESI LOGISTIK BINER DAN PROBIT BINER DALAM PEMODELAN TINGKAT PARTISIPASI ANGKATAN KERJA
}

\author{
Hendra H. Dukalang ${ }^{1 *}$ \\ ${ }^{1}$ Jurusan Perbankan Syariah, IAIN Sultan Amai Gorontalo. Kabupaten Gorontalo 96210, Indonesia \\ *Penulis Korespondensi. Email: hendra.statistika@iaingorontalo.ac.id
}

\begin{abstract}
Abstrak
Regresi merupakan suatu metode analisis data yang digunakan untuk memodelkan hubungan antara satu variabel respon dan satu atau lebih variabel prediktor. Dalam pemodelan regresi sering digunakan data pada umumnya meodel regresi yang sering digunakan adalah sederhana maupun regresi berganda dalam pemodelan yang variabel responnya adalah data kuantitatif. Perbedaan mendasar dari model regresi dengan menggunakan data kuantitatif tujuan utamanya adalah mengestimasi nilai rata-rata dari variabel dependen dengan menggunakan nilai-nilai tertentu dari variabel independen. Sedangkan dalam model regresi dengan variabel dependen kualitatif, tujuan utamanya adalah menemukan probabilitas terjadinya sesuatu (probability model). Salah Satu metode pengembangan dari model regresi untuk data dengan variabel respon kualitatif adalah adalah regresi Logistik dan Probit. Tujuan Penelitian ini adalah membandingkan Model terbaik dengan menggunkan regresi logistic biner dengan regresi probit biner pada kasus Tingkat Partisipasi Angkatan Kerja (TPAK) di Kota Gorontalo. Metode penelitian yang digunakan adalah metode penelitian kuantitatif, dengan pemodelan regresi logistik biner dan regresi probit biner.. Hasil penelitian menunjukan bahwa variable yang berpengaruh signifikan pada TPAK Kota Gorontalo adalah tingkat pengangguran terbuka, dan model terbaik antara model regresi logistic biner dengan nilai AIC sebesar 1,289 lebih kecil dari nilai AIC regresi Probit biner 1,318, demikian pula dari nilai R2 diperoleh nilai R2 untuk regresi logistic biner sebesar $12,74 \%$, lebih besar dari nilai R2 regresi probit biner sebesar $10,70 \%$.
\end{abstract}

Kata Kunci: Regresi; Logistik Biner; Probit Biner; TPAK

\begin{abstract}
Regression is a data analysis method used to model the relationship between one response variable and one or more predictor variables. In regression modelling, data is often used. In general, the regression model that is often used is simple or multiple regression in modelling where the response variable is quantitative data. The fundamental difference from regression models using quantitative data is the main objective is to estimate the average value of the dependent variable using certain values of the independent variable. Whereas in a regression model with a qualitative dependent variable the main objective is to find the probability of something happening (probability model). One of the development methods of the regression model for data with qualitative response variables is Logistic and Probit regression. The purpose of this study was to compare the best model using binary logistic regression with binary probit regression in the case of Labor Force Participation Rate (TPAK) in Gorontalo City. The research method used is quantitative research methods, with binary logistic regression modelling and binary probit regression. The results showed that the variable that has a significant effect on TPAK Gorontalo City is the open unemployment rate, and the best model between the binary logistic regression model with an AIC value of 1.289 is smaller than the AIC value of the binary Probit regression 1.318, likewise from the $R 2$ value the $R 2$ value for regression is obtained. binary logistic of $12.74 \%$, greater than the $R 2$ value of binary probit regression of $10.70 \%$.
\end{abstract}

Keywords: Regression; Binary Logistics; Binary Probit; TPAK 


\section{Pendahuluan}

Hubungan antar variable independen dan dependen dapat dimodelkan degan menggunakan Analisis Regresi. Metode regresi merupakan analisis data yang mendiskripsikan hubungan antara sebuah respon dan satu atau lebih prediktor [1]. Akan tetapi pada umumnya meodel regresi yang sering digunakan adalah sederhana maupun regresi berganda dalam pemodelan yang variabel responnya adalah data kuantitatif. Namun terkadang dalam beberapa kasus, sering di temuai variabel responnya merupakan variabel dengan data kualitatif. Sehingga di perlukan suatu metode yang dapat digunakan dalam menyelesaikan permasalahan tersebut.

Perbedaan mendasar dari model regresi dengan menggunakan data kuantitatif tujuan utamanya adalah mengestimasi nilai rata-rata dari variabel dependen dengan menggunakan nilai-nilai tertentu dari variabel independen. Sedangkan dalam model regresi dengan variabel dependen kualitatif, tujuan utamanya adalah menemukan probabilitas terjadinya sesuatu (probability model). Salah Satu metode pengembangan dari model regresi untuk data dengan variabel respon kualitatif adalah adalah regresi Logistik dan Probit.

Regresi logistik merupakan salah satu metode yang dapat digunakan untuk mencari hubungan respon yang bersifat dichtomous (berskala nominal atau ordinal dengan dua kategori) atau polychotomous prediktor [2]. Regresi logistik mirip dengan analisis diskriminan untuk menguji probability terjadianya variabel dependen yang diprediksi dengan menggunakan variabel dependentnya. Dalam pemodelan regresi logistik sering dikatakan model regresi binary respon. Sehingga jika di kaitkan dengan analisis diskriminan Masalah dalam model regresi logistik dapat di selesaikan dengan analisisi diskriminan, akan tetapi asumsi normal multivariat dalam analisisi diskriminana tidak dapat terpenuhi, karena variabel dependen dalam model merupakan campuran antara variabel metrik (kontinyu) dan non metrik (kategorikal). Dalam pemodelan regresi logistik tidak diperlukan pemenuhan asumsi normal multivariat sehingga regresi logistik dapat menjadi solusi jika asusmsi normal multivariat tidak terpenuhi.

Dalam mengestimasi model regresi logistik digunakan Cumulative logistic function (Fungsi komulatif logistik). Sedangkan fungsi komulatif logistik bukan merupakan satu-satunya Cumulative distribution function (CDF). Dalam perkembangannya model estimasi dengan menggunakan Normal Cumulative distribution function lebih sesui untuk pemodelan variabel dependen kualitatif dan variabel prediktor bersifat kualitatif, kuantitatif, maupun gabungan. Model regresi ini disebut dengan regresi probit. Regresi probit singkatan dari Probability Unit merupakan model berdasarkan fungsi sebaran peluang normal kumulatif baku. Model regresi logistik dan regresi probit merupakan pendekatan alternatif untuk memodelkan hubungan antara variabel respon kategorik dan variabel bebas, dimana variabel respon berdistribusi Bernoulli atau multinomial [3].

Penggunaan model logit sering kali digunakan dalam data klasifikasi [4]. Dalam beberapa penelitian yeng menggunakan pemodelan regresi logistik dan regresi probit diantaranya adalah Penggunaan metode Least Absolute Deviation (LAD) untuk mengestimasi parameter model [5], Pengujian hipotesis dengan parameter robust [6] penggunaan metode Maximum Likelihood Estimation (MLE) untuk mengestimasi model, pendekatan numerik dan estimasi parameter serta diagnosis terhadap model [7]. Pemilihan model terbaik dengan kriteria $C p$ Mallows dan AIC (Akaike's Information Criterion)[8]. Peneltian untuk pemodelan regresi probit talah digunakan dalam Pemodelan dan prediksi kebangkrutan bank di Slovakia [9], Regresi probit untuk variabel pengontrol hubungan antara variabel prediktor dan variabel respon [10]. Pemodelan regresi probit dan aplikasinya untuk data mining [11] Pemodelan Ketahanan Pangan di Indonesi dengan pendekatan regresi probit ordinal [12].

Dalam penelitian ini regresi logistik dan regresi probit di implementasikan dalam pemodelan Pemodelan Angkatan Kerja Di Kota Gorontalo. Menurut BPS Kota Gorontalo laju pertumbuhan penduduk Kota Gorontalo dapat menimbulkan berbagai tekanan dalam berbagai aspek kehidupan dan berimpilikasi dalam penyediaan lapangan kerja bagi angkatan kerja yang ada, karena bila penduduk 
bertambah maka jumlah angkatan kerja bertambah sehingga dapat menimbulkan masalah bagi penyediaan lapangan kerja baru. Penelitian ini bertujuan untuk mendapatkan model regresi terbaik pada pemodelan Angkatan Kerja di Kota Gorontalo, sehingga mendapatkan faktor-faktor yang mempengaruhi Tingkat partisi angkatan kerja di Kota Gorontalo.

\section{Metode Penelitian}

Penelitian ini menggunakan metode penelitian kuantitatif. Data yang digunakan dalam penelitian ini adalah data sekunder yang di peroleh dari Dinas tenaga Kerja, UKM dan Koperasi di Kota Gorontalo. Variabel yang digunakan meliputi Tingkat Partisipasi Angkatan Kerja (TPAK) sebagai Variabel Y, dengan kategori 0 apabila kelurahan masuk dalam tingkat partisipasi Angkatan kerja rendah, serta kategori 1 apabila kelurahan masuk dalam tingkat partisipasi Angkatan kerja tinggi. Variabel prediktor yang digunakan dalam penelitian ini sebanyak 6 variabel dengan tipe kontinu, yaitu presentase usia produktif (X1), Tingkat pengangguran terbuka (X2), presentase pendidikan SD (X3), presentase Pendidikan SMP (X4), presentase Pendidikan SMA (X5), presentase Pendidikan PT (X6). Unit pengamatan yang digunakan dalam penelitian ini adalah kelurahan di Kota Gorontalo yang terdiri dari 50 Kelurahan. Sehingga jumlah keseluruhan dari unit pengamatan adalah sebanyak 50 kelurahan.

Metode analisis data untuk pemodelan tingkat partisipasi angkatan kerja (TPAK) dengan regresi logistik dan regresi probit adalah sebagai berikut :

1. Melakukan analisis statistika deskriptif terhadap variabel respon dan variabel prediktor

2. Melakukan pengujian multikolinieritas pada variabel prediktor, untuk mengetahui interdependensi antar variabel prediktor. Apabila terjadi multikoliinieritas maka diatasai dengan backward eliminasi.

$V I F=\frac{1}{1-R_{s}^{2}}$, untuk s $=1,2, \ldots, \mathrm{p}$, dimana $R_{s}^{2}=1-\frac{\sum_{i=1}^{N}\left(x_{i}-\hat{x}_{i}\right)^{2}}{\sum_{i=1}^{N}\left(x_{i}-\bar{x}_{i}\right)^{2}}$

3. Mengestimasi parameter regresi logistik untuk mengetahui hubungan antar variabel prediktopr dan variabel respon menggunakan Metode Maximum Likelihood. Metode tersebut mengestimasi parameter $\beta$ dengan cara memaksimumkan fungsi likelihood

4. Melakukan pengujian signifikansi parameter dengan melakukan uji serentak menggunakan persamaan

$G=-2 \ln \frac{\left[\frac{n_{1}}{n}\right]^{n_{1}}\left[\frac{n_{0}}{n}\right]^{n_{0}}}{\prod_{j=1}^{n} \hat{\pi}_{j}^{y_{i}}\left[1-\hat{\pi}_{j}\right]^{1-y_{j}}}$

5. Melakukan pengujian signifikansi parameter dengan melakukan uji parsial menggunakan persamaan.

$W_{i}=\frac{\hat{\beta}_{j}}{S E\left(\hat{\beta}_{j}\right)}$

6. Melakukan uji kesesuaian model untuk mengetahui apakah model yang didapatkan telah sesuai atau tidak.

$\hat{C}=\sum_{k=1}^{g} \frac{\left(o_{k}-n^{\prime}{ }_{k} \overline{\hat{\pi}}_{k}\right)^{2}}{n_{k}{ }_{k} \overline{\hat{\pi}}_{k}\left(1-\overline{\hat{\pi}}_{k}\right)}$

7. Menghitung ketepatan klasifikasi model dengan persamana 1 - APER, dimana APER (apparent error rate) menggunakan persamaan berikut:

$A P E R=\frac{n_{1 M}+n_{2 M}}{n_{1}+n_{2}} \times 100 \%$. 
8. Pemilihan Model terbaik menggunakan Pseudo $R^{2}$ McFadden dengan persamaan sebeagi berikut:

$$
R_{M F}^{2}=1-\frac{\log L_{1}}{\log L_{0}}=1-\ln \left(\frac{\left[\frac{n_{1}}{n}\right]^{n_{1}}\left[\frac{n_{0}}{n}\right]^{n_{0}}}{\prod_{j=1}^{n} \hat{\pi}_{j}^{y_{i}}\left[1-\hat{\pi}_{j}\right]^{1-y_{j}}}\right)
$$

9. Membuat kesimpulan dan saran dari hasil penelitian.

Pengolahan dan analisis data untuk estimasi dan pengujian hipotesis parameter menggunakan software eviews 10 .

\section{Hasil dan Pembahasan}

\subsection{Karakteristik Variabel Respon Dan Variabel Prediktor.}

\subsubsection{Karakteristik Variabel Respon}

Variabel respon yang digunakan dalam penelitian ini adalah partisipasi Angkatan kerja (TPAK) di Kota Gorontalo. TPAK yang tersebar di 50 kelurahan di Kota Gorontalo. Status tingkat partisipasi Angkatan kerja dikategorikan menjadi dua kategori, yaitu kategori yakni kategori tinggi dan kategori rendah. Berikut hasil pengujian deskriptif untuk tingkat partisipasi angkatan kerja di Kota Gorontalo. Dari 50 Kelurahan yang ada di Kota Gorontalo, terdapat 25 kelurahan yang masuk dalam kategori tingkat partisipasi Angkatan kerja kategori rendah. Sedangkan 25 kelurahan lainnya masuk dalam kategori kategori tingkat partisipasi Angkatan kerja kategori tinggi.

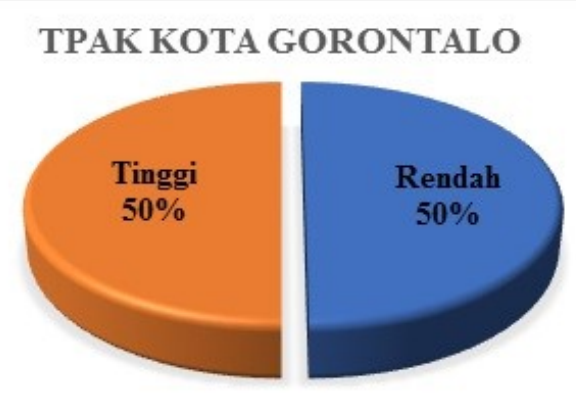

Gambar 1. Presentase Tingkat Partisipasi Angkatan Kerja

\subsubsection{Karakteristik Variabel Prediktor}

Variabel prediktor yang digunakan dalam penelitian ini sebanyak 6 variabel dengan tipe kontinu, yaitu presentase usia produktif (X1), Tingkat pengangguran terbuka (X2), presentase pendidikan Sekolah Dasar (X3), presentase Pendidikan SMP (X4), presentase Pendidikan SMA (X5), presentase Pendidikan Tinggi (X6), Karena data yang digunakan dalam variabel prediktor merupakan data interval maka Analisis statistika deskriptif yang digunakan untuk mendapatkan informasi dari seluruh variabel menggunakan nilai mean, standar deviasi, minimum, dan maksimum.

Tabel 1. Deskriptif Variabel Prediktor

\begin{tabular}{ccccc}
\hline Variable & Mean & StDev & Minimum & Maximum \\
\hline X1 & 40.179 & 1.499 & 36.42 & 43.37 \\
X2 & 20.392 & 4.465 & 10.14 & 37.82 \\
X3 & 12.064 & 4.645 & 5.4 & 26.15 \\
X4 & 11.588 & 1.866 & 6.06 & 15.91 \\
X5 & 26.023 & 5.274 & 12.01 & 36.66 \\
X6 & 7.366 & 3.025 & 2.13 & 14.55 \\
\hline
\end{tabular}


Tabel 1 menunjukan bahwa usia produktif pekerja yaitu 45-45 tahun di kota Gorontalo memiliki rata-rata 40,179 persen, dengan standar deviasi sebesar 1,499 dengan nilai minimum sebesar 36,42 persen dan nilai maksimum 43,37 persen. Serta Tingkat pengangguran terbuka di kota Gorontalo memiliki rata-rata 20,392 persen, dengan standar deviasi sebesar 4,465 dengan nilai minimum sebesar 10,14 persen dan nilai maksimum 37,82 persen. Tingkat pendidikan SD di kota Gorontalo memiliki rata-rata 12,064 persen, dengan standar deviasi sebesar 4,645 dengan nilai minimum sebesar 5,4 persen dan nilai maksimum 26,15 persen. Tingkat Pendidikan SMP kota Gorontalo memiliki ratarata 11,588 persen, dengan standar deviasi sebesar 1,866 dengan nilai minimum sebesar 6,06 persen dan nilai maksimum 15,91 persen. Untuk Tingkat Pendidikan SMA di kota Gorontalo memiliki ratarata 22,023 persen, dengan standar deviasi sebesar 5,274 dengan nilai minimum sebesar 12,01 persen dan nilai maksimum 36,66 persen. Selanjutnya tingkat Pendidikan perguruan tinggi di kota Gorontalo memiliki rata-rata 7,366 persen, dengan standar deviasi sebesar 3,025 dengan nilai minimum sebesar 2,13 persen dan nilai maksimum 14,55 persen.

\subsection{Pengujian Asumsi Multikolinieritas}

Uji multikolinieritas merupakan suatu pengujian yang dilakukan untuk mengetahui ada atau tidaknya hubungan secara linier antar variabel prediktor. Dalam Analisis regresi logistic biner dan regresi probit biner tidak diperkenankan adanya hubungan secara linier antara variabel prediktor sehingga pelu dilakukan uji multikolinieritas sebelum melakukan pemodelan menggunakan regresi logistic biner maupun regresi probit biner.

Berdasarkan hasil pengujian korelasi antar variabel prediktor, tidak terdapat korelasi yang lebih dari 0,80. Sehingga dapat disimpulkan bahwa tidak terdapat multikolinieritas antar variabel prediktor. Hasil ini juga sesuai dengan pengujian menggunakan nilai Variance Inflating Factor (VIF), sehingga diperoleh hasil pengujian multikolinieritas yang disajikan pada Tabel 2.

Tabel 2. Hasil Uji Multikolinieritas

\begin{tabular}{ccc}
\hline Variabel & Nilai VIF & Keterangan \\
\hline X1 & 1,18 & Tidak terjadi multikolinieritas \\
X2 & 1,50 & Tidak terjadi multikolinieritas \\
X3 & 3,14 & Tidak terjadi multikolinieritas \\
X4 & 1,70 & Tidak terjadi multikolinieritas \\
X5 & 3,64 & Tidak terjadi multikolinieritas \\
X6 & 2,23 & Tidak terjadi multikolinieritas \\
\hline
\end{tabular}

Berdasarkan Tabel 2 ditunjukan bahwa hasil pengujian asumsi multikolinieritas tidak terjadi masalah dalam multikolinieritas, Karena Nilai VIF kurang dari 10,00. Sehingga dapat dilanjutkan pada pemodelan dengan menggunakan regresi logistic biner dan regresi probit biner.

\subsection{Model Regresi Logistik Biner}

\subsubsection{Pengujian parameter secara serentak Regresi Logistik Biner}

Pengujian parameter secara serentak digunakan untuk memeriksa keberartian koefisien $\beta$ secara keseluruhan dengan variabel prediktor Uji serentak pada penelitian ini menggunakan likelihood ratio test $\left(\mathrm{G}^{2}\right)$ dengan $\alpha(0,10)$.. Berdasarkan hasil pengujian parameter secara serentak diperoleh p-value sebesar 0,033. Nilai tersebut kurang dari nilai alpha, serta nilai chi square sebesar $13,70>2,706$ sehingga dapat dikatakan bahwa $\mathrm{H}$ ditolak yang berarti bahwa pada tingkat kepercayaan sebesar 90 persen minimal terdapat satu parameter yang signifikan pada model. 


\subsubsection{Pengujian parameter secara parsial Regresi Logistik Biner}

Pengujian parameter secara parsial digunakan untuk mengetahui keberartian koefisien $\beta$ dari masing-masing variabel prediktor yaitu X1 dan X6 secara individu. hipotesis yang digunakan

$\mathrm{H}_{0}: \beta=0$

$\mathrm{H}_{1}: \beta \neq 0$

Kriteria pengujian, Tolak H0 jika nilai $W_{s}^{2}>\chi_{(d f, \alpha)}^{2}$ atau p-value $<\alpha(0,10)$.

Pengujian parameter secara parsial pada penelitian ini menggunakan uji Wald. Hasil pengujian parameter secara parsial adalah variable predictor dengan nilai $\mathrm{p}$-value sebesar $0,0154<\alpha(0,10)$., dengan nilai chi-square sebesar 2,822. Lebih besar dari chi-square table 2,706. Sehingga hanya variabel tingkat pengangguran terbuka yang dimasukkan dalam model regresi logistik biner.

\subsection{Model Regresi Logistik Biner}

Variabel prediktor yang signifikan yang merupakan hasil yang diperoleh dari uji serentak dan uji parsial yaitu X digunakan untuk membentuk model regresi logisti biner terbaik. Berikut adalah model regresi logistik biner yang dapat di bentuk berdasarkan persamaan:

$$
\operatorname{Ln}\left(\frac{p}{1-p}\right)=g(x)=-5,074+0,2512 X_{2}
$$

Sehingga dapat di peroleh formula untuk mencari nilai probabilitas adalah sebagai berikut:

$$
P=\frac{e^{g(x)}}{1+e^{g(x)}}
$$

Dimana $g(x)=-5,074+0,2512 X_{2}$

Berdasarkan model yang terbentuk variabilitas variabel respon yang dapat dijelaskan oleh variabel prediktor sangat kecil yaitu sebesar $12,74 \%$ yang menunjukan pemodelan yang terbentuk kurang bagus, hal ini dapat terlihat dari nilai $R$-Square sebesar $12,74 \%$. Selanjutnya unttuk menguji apakah terdapat perbedaan antara hasil observasi dengan kemungkinan hasil prediksi model. Maka digunakan hasil pengujian Hosmer and Lemeshow.

Hipotesis prediksi)

$\mathrm{H}_{0}$ : Model sesuai (Tidak terdapat perbedaan antara hasil observasi dengan kemungkinan hasil

$\mathrm{H}_{1}$ : Model tidak sesuai (terdapat perbedaan antara hasil observasi dengan kemungkinan hasil prediksi)

Kriteria pengujian, Tolak H0 jika nilai $\hat{C}>\chi_{(d f, \alpha)}^{2}$ atau p-value $<\alpha(0,10)$.

Berdasarkan hasil pengujian Hosmer and Lemeshow diperoleh bahwa nilainya sebesar 6,396 < 62,038 tidak terdapat perbedaan antara hasil observasi dengan hasil prediksi yang diperoleh menggunakan model yang telah terbentuk dimana hal ini dapat diketahui dari nilai p-value $(0,603)>$ nilai $\alpha(0,10)$. sehingga gagal tolak $\mathrm{H}_{0}$.

\subsection{Ketepatan Klasifikasi Model Regresi Logistik Biner}

Maka model yang terbentuk berdasarkan variabel yang ada sudah sesuai. Kesesuaian model juga dapat ditunjukan dari persentase ketepatan klasifikasi. Berikut ini ketepatan klasifikasi model yang terbentuk pada Tabel 3. 
Tabel 3 Ketepatan Klasifikasi Model Regresi Logistik Biner

\begin{tabular}{ccccc}
\hline \multirow{2}{*}{ Observasi } & \multicolumn{3}{c}{ Prediksi } \\
\cline { 2 - 5 } & & \multicolumn{2}{c}{ TPAK } & Presentase Kebenaran \\
\cline { 2 - 5 } & Rendah & Tinggi \\
\hline \multirow{2}{*}{ TPAK } & Rendah & 22 & 9 & $88,0 \%$ \\
\multirow{2}{*}{ Presentase Keseluruhan } & Tinggi & 3 & 16 & $64,0 \%$ \\
& & & $76,0 \%$ \\
\hline
\end{tabular}

Berdasarkan tabel ketepatan klasifikasi pada tabel 3 diketahui tingkat persentase kebenaran pada tingkat rendah sangat baik yaitu sebesar $88 \%$ sedangkan tingkat persentase ketepatan klasifikasi pada tingkat tinggi juga baik yaitu 64\%. Secara keseluruhan tingkat persentase kebenaran cukup tinggi yaitu sebesar $76 \%$.

\subsection{Model Regresi Probit Biner}

\subsubsection{Pengujian parameter secara serentak Regresi Probit Biner}

Pengujian parameter secara serentak digunakan untuk memeriksa keberartian koefisien $\beta$ secara keseluruhan dengan variabel prediktor. Uji serentak pada penelitian ini menggunakan likelihood ratio test $\left(\mathrm{G}^{2}\right)$ dengan $\alpha(0,10)$. Berdasarkan hasil pengujian parameter secara serentak diperoleh p-value sebesar 0,043. Nilai tersebut kurang dari nilai alpha, serta nilai chi square sebesar 12,97 sehingga dapat dikatakan bahwa $\mathrm{H}$ ditolak yang berarti bahwa pada tingkat kepercayaan sebesar 90 persen minimal terdapat satu parameter yang signifikan pada model.

\subsubsection{Pengujian parameter secara parsial Regresi Probit Biner}

Pengujian parameter secara parsial digunakan untuk mengetahui keberartian koefisien $\beta$ dari masing-masing variabel prediktor yaitu X1 dan X6 secara individu. hipotesis yang digunakan

$$
\begin{aligned}
& \mathrm{H}_{0}: \beta=0 \\
& \mathrm{H}_{1}: \beta \neq 0
\end{aligned}
$$

Kriteria pengujian, Tolak H0 jika nilai $W^{2}>\chi_{(d f, \alpha)}^{2}$ atau p-value $<\alpha(0,10)$. Pengujian parameter secara parsial pada penelitian ini menggunakan uji Wald. Hasil pengujian parameter secara parsial adalah variable predictor dengan nilai $\mathrm{p}$-value $<\alpha(0,10)$ adalah variabel tingkat pengangguran terbuka, yakni sebesar 0,013 dengan nilai chi-square sebesar 2,901. Lebih besar dari chi-square table 2,706 Sehingga hanya variable tersebut yang dimasukkan dalam model regresi probit biner.

\subsubsection{Model Regresi Probit Biner}

Variabel prediktor yang signifikan yang merupakan hasil yang diperoleh dari uji serentak dan uji parsial yaitu X digunakan untuk membentuk model regresi probit biner terbaik. Berikut adalah model regresi probit biner yang dapat di bentuk adalah:

$$
\begin{aligned}
& \hat{p}(Y=0)=\Phi\left(-2,287+0,1116 X_{2}\right) \\
& \hat{p}(Y=1)=1-\Phi\left(-2,287+0,1116 X_{2}\right)
\end{aligned}
$$

Berdasarkan model yang terbentuk variabilitas variabel respon yang dapat dijelaskan oleh variabel prediktor sangat kecil yaitu sebesar $10,70 \%$ yang menunjukan pemodelan yang terbentuk kurang bagus, hal ini dapat terlihat dari nilai R-Square sebesar 10,70\%. 
Selanjutnya unttuk menguji apakah terdapat perbedaan antara hasil observasi dengan kemungkinan hasil prediksi model. Maka digunakan hasil pengujian Hosmer and Lemeshow. Hipotesis yang digunakan dalam pengujian model adalah sebagai berikut. prediksi)

$\mathrm{H}_{0}$ : Model sesuai (Tidak terdapat perbedaan antara hasil observasi dengan kemungkinan hasil prediksi)

Kriteria pengujian, Tolak H0 jika nilai $\hat{C}>\chi_{(d f, \alpha)}^{2}$ atau p-value $<\alpha(0,10)$

Berdasarkan hasil pengujian Hosmer and Lemeshow diperoleh bahwa tidak terdapat perbedaan antara hasil observasi dengan hasil prediksi yang diperoleh menggunakan model yang telah terbentuk dimana hal ini dapat diketahui dari nilai $\mathrm{p}$-value $(0,4515)>$ nilai $\alpha(0,10)$ sehingga gagal tolak $\mathrm{H}_{0}$ atau model sudah sesuai.

\subsubsection{Ketepatan Klasifikasi Model Regresi Probit Biner}

Untuk Menunjukan keseuai model dapat dikuatkan dengan menggunakan ketepatan klasifikasi model yang terbentuk, sebagaimana ditunjukkan pada Tabel 4 .

Tabel 4. Ketepatan Klasifikasi Model

\begin{tabular}{ccccc}
\hline \multirow{2}{*}{ Observasi } & \multicolumn{3}{c}{ Prediksi } \\
\cline { 2 - 4 } & \multicolumn{2}{c}{ TPAK } & $\begin{array}{l}\text { Presentase } \\
\text { Kebenaran }\end{array}$ \\
\cline { 2 - 4 } & Rendah & Tinggi \\
\hline \multirow{2}{*}{ TPAK } & Rendah & 22 & 9 & $88,0 \%$ \\
\multicolumn{2}{|c}{ Presentase Keseluruhan } & 3 & 16 & $64,0 \%$ \\
\hline
\end{tabular}

Berdasarkan tabel ketepatan klasifikasi pada tabel 4 diketahui tingkat persentase kebenaran pada tingkat rendah sangat baik yaitu sebesar $88 \%$ sedangkan tingkat persentase ketepatan klasifikasi pada tingkat tinggi juga baik yaitu 64\%. Secara keseluruhan tingkat persentase kebenaran cukup tinggi yaitu sebesar $76 \%$

\subsection{Pemilihan Model Terbaik}

Pemilihan model terbaik dealam penelitian ini menggunakan kriteria pemilihan model terbaik AIC (Aikake Information Criterion) sebagaimana ditunjukkan pada Tabel 5.

Tabel 5. Perbandingan Model Terbaik

\begin{tabular}{ccc}
\hline Model & AIC & $\mathrm{R}^{2}$ \\
\hline Regresi Logistik Biner & 1,289 & $12,74 \%$ \\
Regresi Probit Biner & 1,318 & $10,70 \%$ \\
\hline
\end{tabular}

Berdasarkan tabel 5 diperoleh bahwa nilai AIC terkecil adalah model regresi logistic biner dengan nilai AIC sebesar 1,289 sedangkan nilai AIC untuk model regresi probit biner sebesar 1,318. Hal ini dapat disimpulkan bahwa model terbaik adalah model regresi logistic biner. Hal ini sesuai dengan nilai dari $\mathrm{R}^{2}$, di mana nilai $\mathrm{R}^{2}$ terbesar merupakan $\mathrm{R}^{2}$ dari model regresi logistic biner yaitu sebesar $12,74 \%$. Sedangakan nilai $\mathrm{R}^{2}$ dari model regresi probit biner yaitu sebesar $10,70 \%$. 


\section{Kesimpulan}

Berdasarkan hasil analisis dan pembahasn di simpulkan bahwa TPAK dengan kategori tinggi sebanyak 50\% dan kategori rendah 50\%, dengan rata-rata usia adalah 40 tahun, dan tingkat penganggaran terbuka adalah $20 \%$. Variabel yang berpengaruh signifikan pada model regresi logistk biner adalah variabel tingkat pengangguran terbuka dengan koefisien 0,2512. Variabel yang berpengaruh signifikan pada model regresi probit biner adalah variabel tingkat pengangguran terbuka dengan koefisien 0,1116, sedangkan model terbaik adalah regresi logistik biner dengan nilai AIC lebih kecil dari regresi probit biner, dan nilai $\mathrm{R}^{2}$ regresi logistik biner lebih besar dari nilai $\mathrm{R}^{2}$ regresi probit biner.

\section{Referensi}

[1] D.W. Hosmer, S. Lemeshow, R.X. Sturdivant, Applied logistic regression, 3rd Edition. John Wiley \& Sons, 2013.

[2] A. Agresti, Categorical data analysis, 3rd Edition. John Wiley \& Sons, 2013.

[3] D.J. Finney, Probit analysis, 3rd Edition. Cambridge University Press, 1971

[4] Gujarati, Damodar. Dasar-dasar Ekonometrika, Edisi Kelima. Mangunsong, R. C. penerjemah. Jakarta: Salemba Empat. 2013

[5] S. Hosseinian, E. Martinez, Robust binary regression. Journal of Statistical Planning and Inference, 141, 1497-1509, 2011

[6] A.M. Bianco, E. Martinez, Robust testing in the logistic regression model. Computational Statistics and Data Analysis, 53, 4095-4105, 2009.

[7] D. Pregibon, Logistic regression diagnostics. The Annals of Statistics, 9, 705-724, 1981.

[8] D.W. Hosmer, B. Jovanovic, S. Lemeshow, Best subsets logistic regression. Biometrics, 45, 1265-1270, 1989.

[9] T. Kliestik, K. Kocisova, M. Misankova, Logit and probit model used for prediction of financial health of company. Procedia Economics and Finance, 23, 850-855, 2015.

[10] K.B. Karlson, A. Holm, R. Breen, Comparing regression coefficients between same-sample nested models using logit and probit: a new method. Sociological Methodology, 42, 286-313, 2012.

[11] M. Razzaghi, The probit link function in generalized linear models for data mining applications. Journal of Modern Applied Statistical Methods, 12, 164169, 2013.

[12] Permatasari, D.L. dan Ratnasaril V. Pemodelan Ketahanan Pangan di Indonesia dengan Pendekatan Regresi Probit Ordinal. Jurnal Sains dan Seni ITS, Vol.5, No.2, Hal:151-156. 2016. 